\title{
Pengaruh Populasi Tanaman terhadap Pertumbuhan dan Hasil Beberapa Varietas Jagung ( Zea Mays L.) Lokal di Lahan Kering
}

Eduardus Yosef Neonbeni ${ }^{a}$, I. G. A Mas Sri Agung ${ }^{\mathrm{b}}$ \& I Made Suarna ${ }^{\mathrm{c}}$

${ }^{a}$ Fakultas Pertanian, Universitas Timor, Kefamenanu, TTU - NTT, Indonesia, email: ambeni02@gmail.com

${ }^{b}$ Fakultas Pertanian, Universitas Udayana, Bali-Indonesia, email: igamassriagung@gmail.com

${ }^{c}$ Fakultas Peternakan, Universitas Udayana, Bali-Indonesia, email: imadesuarna12@gmail.com

\section{Article Info}

Article history:

Received 18 Desember 2018

Received in revised form 28 Desember 2018

Accepted 15 Januari 2019

DOI:

https://doi.org/10.32938/sc.v4i01.298

Keywords:

Populasi Tanaman

Varietas Lokal

Zea mays $\mathrm{L}$.

Lahan Kering

\section{Abstrak}

Penelitian di lahan kering bertujuan untuk mengetahui populasi tanaman yang berpengaruh meningkatkan pertumbuhan dan hasil jagung varietas lokal mengounakan rancangan acak kelompok dengan dua faktor yaitu populasi sebagai faktor pertama terdiri dari taraf perlakuan populasi 285.714 tan ha ${ }^{-1}, 357.143$ tan ha $^{-1}, 428.71$ tan ha $^{-1}$ dan 500.000 tan ha ${ }^{-1}$, yang diperoleh dengan menanam jagung sejumlah 4 tan.lubang ${ }^{-1}, 5$ tan.lubang ${ }^{-1}, 6$ tan.lubang ${ }^{-1}$ dan 7 tan.lubang ${ }^{-1}$ dalam jarak tanam $70 \mathrm{~cm}$ x $20 \mathrm{~cm}$. Faktor kedua adalah varietas jagung terdiri dari taraf perlakuan Varietas Lokal Bukit, Lokal Kefa 1, Lokal Kefa 2 dan Bisi 2 sebagai kontrol. Hasil penelitian menunjukkan bahwa pada populasi 285.714 diperoleh hasil dengan berat biji kadar air $12 \% 7,78 \mathrm{~g} \mathrm{tongkol}^{-1}$ dan berat biji kering oven 7,73g tongkol ${ }^{-1}$, dihasilkan oleh varietas lokal bukit. Populasi 285,714 tan.ha- $\mathrm{h}^{-1}$ secara tunggal memberikan hasil dengan berat biji kering oven $\tan ^{-1} \operatorname{tertinggi~}^{(135,23 \mathrm{~g}}$ tan.-1) dan berat biji kering oven ha-1 tertinggi $\left(7,73 \mathrm{tha}^{-1}\right)$. Varietas Lokal Bukit secara tunggal memberikan hasil dengan berat biji kering oven 90,20 g tan. ${ }^{-1}$ dan berat biji kering oven $5,13 \mathrm{tha}^{-1}$, berpotensi dikembangkan di lahan kering khususnya di daerah Taman Mumbul, Kuta Selatan pada populasi 285.714 tan.ha $^{-1}\left(4\right.$ tan.lubang $\left.^{-1}\right)$.

\section{Pendahuluan}

Tanaman jagung (Zea mays, L.) di Indonesia merupakan salah satu komoditi utama untuk bahan pangan. Biji jagung sebagai salah satu sumber karbohidrat dan protein dapat diolah menjadi berbagai jenis makanan dan pakan Semua kebutuhan tersebut dapat terpenuhi melalui upaya meningkatkan produks jagung, di antaranya dengan mengelola lahan kering secara lebih intensif untuk budidaya jagung karena lahan pertanian semakin berkurang akibat degradasi dan alih fungsi lahan. Sementara itu jumlah penduduk di Indonesia terus meningkat sehingga kebutuhan akan jagung pun terus meningkat. Hal ini akan terpenuhi bila produksi jagung di Indonesia terus ditingkatkan, di antaranya dengan memperbaiki teknik budidaya jagung di lahan kering. Di Indonesia luas lahan kering mencapai 16-20 juta hektar, namun produktivitas di lahan kering untuk jagung masih rendah yaitu 1-2 $\mathrm{t} \mathrm{ha}^{-1}$ (Amim dan Nurmauli, 2004). Zubachtirodin dkk., (2009) menyatakan bahwa Pertanaman jagung pada MH umumnya diusahakan pada lahan kering, sedangkan pada MK diusahakan pada sawah tadah hujan dan sawah irigasi.

Budidaya jagung di lahan kering selama ini telah dilakukan masyarakat, namun karena rendahnya pengetahuan dan keterbatasan informasi tentang teknologi budidaya, terutama di daerah-daerah lahan kering terpencil, menyebabkan produksi jagung masih rendah. Pemanfaatan lahan kering untuk budidaya jagung selama ini telah dilakukan masyarakat, namun pengelolaannya belum maksimal karena rendahnya pengetahuan dan keterbatasan informasi tentang teknik budidaya yang tepat terutama di daerah-daerah terpencil. Petani di daerah lahan kering pada umumnya adalah petani kecil dengan tingkat perekonomian dan pendidikan yang rendah sehingga mempengaruhi cara bertaninya (Suprapto, dkk., 1999, dalam Yasa $d k k .$, 2006). Petani masih menanam dengan jarak tanam yang tidak teratur dan tidak memperhitungkan efisiensi penggunaan lahan. Oleh karena itu diperlukan upaya meningkatkan produksi jagung di daerah lahan kering dengan cara mengatur populasi tanaman sampai batas optimum, sehingga pemanfaatan lahan lebih efisien dan produks per luasan lahan semakin tinggi.

Penanaman dengan jumlah benih per lubang dan jarak tanam yang tepa (populasi optimum) menyebabkan pertumbuhan tanaman berlangsung dengan baik tanpa mengalami kompetisi, sehingga dapat diperoleh hasil yang tinggi karena tanaman mencapai indeks luas daun yang optimum dimana penyerapan cahaya lebih baik untuk memaksimalkan proses fotosintesis. Gardner dkk., (1991) menyatakan, praktik agronomi seperti kepadatan tumbuhan yang tingg dan pengaturan jarak tanam yang seragam digunakan untuk menambah penutup tanah dan meningkatkan penyerapan cahaya. Tingginya aktivitas fotosintesis berpengaruh terhadap laju pertumbuhan relatif dan hasil asimilasi bersih tanaman (Jumin, 1989).

Populasi yang terlalu tinggi melebihi populasi optimum menyebabkan kompetisi yang tinggi antar tanaman baik dalam memperoleh cahaya, hara dan air maupun ruang tumbuh, sehingga hasil yang diperoleh rendah. Sebaliknya pada populasi yang terlalu rendah menguntungkan bagi pertumbuhan dan produksi per tanaman, tetapi hasil menjadi rendah per satuan luas lahan. Penelitian Wijaya (2005) membuktikan bahwa jagung manis (Zea mays saccharata Sturt) memberikan hasil berupa pucil jagung segar sebanyak 4,29 ha $^{-1}$ pada populasi 120.000 tan.ha $^{-1}($ jarak tanam $50 \mathrm{~cm} \times 16,7 \mathrm{~cm})$, lebih rendah bila dibandingkan dengan populasi 100.000 tan.ha $^{-1}$ (jarak tanam $50 \mathrm{~cm} \mathrm{x} 20 \mathrm{~cm}$ ) yang memberikan hasil pucil jagung segar sebanyak $4,79 \mathrm{t} \mathrm{ha}^{-1}$

Masyarakat di lahan kering juga masih menggunakan jagung varietas lokal karena dianggap cocok dengan kondisi agroekologis lahan kering. Hasil yang tinggi tergantung pada kemampuan genetis jagung yang ditanam dalam memanfaatkan semua faktor tumbuh yang ada, serta ketahanannya terhadap keterbatasan faktor tumbuh di lahan kering, seperti suhu yang tinggi, curah hujan dan kesuburan tanah yang rendah. Penelitian Mediastari (2009) membuktikan bahwa varietas yang cocok dikembangkan di lahan kering adalah varietas loka Bukit Cengiling, yang memberikan hasil yang tinggi berupa berat biji kering kadar air $12 \%\left(9,39 \mathrm{t} \mathrm{ha}^{-1}\right)$ dan berat biji kering oven tertinggi $\left(6,28 \mathrm{t} \mathrm{ha}^{-1}\right)$. Hasil tersebut diperoleh pada populasi 285.714 tan.ha $^{-1}$ (4 tan lubang $\left.{ }^{-1}\right)$ dengan jarak tanam $70 \mathrm{~cm} \times 20 \mathrm{~cm}$.

Masyarakat di Kabupaten Timor Tengah Utara (TTU), Provinsi Nusa Tenggara Timur (NTT), masih menanam beberapa varietas jagung lokal genjah ( \pm 3 bulan), yang disebut pena $m$ 'asa, terdiri dari jagung yang bijinya berwarna kuning (pena molo m'asa) dan putih (pena muti m'asa). Varietas tersebut memiliki potensi cukup tinggi dengan berat kering pipilan antara 5-6 ton ha ${ }^{-1}$ bila ditanam pada tanah subur dan dipelihara dengan baik (pers. com.). Namun menurut BKPMD Provinsi Nusa Tenggara Timur (NTT) (2008), rata-rata produktivitas jagung di Kabupaten TTU masih rendah, yaitu sebesar 2,357 ton $\mathrm{ha}^{-1}$. Masyarakat di TTU yang menanam jagung berada di lahan kering dari dataran sedang sampai tinggi dengan topografi berbukit. Penanaman biasanya dilakukan dengan jumlah empat sampai lima benih lubang ${ }^{-1}$, jarak tanam tidak teratur (pers. com.)

Populasi optimum berbeda-beda antara satu varietas dengan varietas yang lain, sesuai karakteristik masing-masing varietas dan dipengaruhi pula oleh faktor lingkungan. Hasil penelitian membuktikan bahwa populasi jagung masih dapat ditingkatkan, tergantung varietas yang ditanam dan dipengaruhi oleh keadaan lingkungan di tempat percobaan. Hasil penelitian yang dilakukan Sudiana (2007) membuktikan berat biji kering panen $\tan ^{-1}(297,5 \mathrm{~g})$ diberikan oleh BISI-2 pada populasi 47.619 tan. ha $^{-1}$ berbeda nyata $(\mathrm{P}<0,05)$ dengan semua populasi tanaman dan varietas lain.

Berdasarkan berbagai persoalan di atas maka perlu dilakukan penelitian untuk mengetahui pengaruh interaksi antara populasi dan varietas terhadap produksi jagung, serta mengetahui populasi optimum jagung varietas lokal yang menghasilkan produksi tertinggi.

\section{Metode}

Penelitian telah dilakukan pada akhir bulan Oktober 2009 sampai dengan Maret 2010, dimulai dengan persiapan lahan terdiri dari pembersihan dan pengolahan tanah, persiapan benih, penanaman sampai dengan panen, diserta pengamatan parameter lingkungan, pertumbuhan dan hasil. Lokasi penelitian di lahan kering lingkungan Taman Mumbul, Kelurahan Benoa, Kecamatan Kuta Selatan, Kabupaten Badung. Tempat penelitian berada pada ketinggian $87 \mathrm{~m}$ dpl. Percobaan menggunakan Rancangan Acak Kelompok (RAK) dengan perlakuan yang disusun secara faktorial (Gomez dan Gomez, 1995). Perlakuan yang digunakan terdiri dari dua faktor. Faktor Populasi (P) terdiri dari level perlakuan $\mathrm{P}_{1}$ : Populasi 285.714 tanaman ha $^{-1}$ (4 tanaman lubang $\left.{ }^{-1}\right), \mathrm{P}_{2}$ : Populas 357.143 tanaman ha $^{-1}\left(5\right.$ tanaman lubang $\left.{ }^{-1}\right), \mathrm{P}_{3}$ : Populasi 428.571 tanaman ha (6 tanaman lubang ${ }^{-1}$ ) dan $\mathrm{P}_{4}$ : Populasi 500.000 tanaman $\mathrm{ha}^{-1}$ (7 tanaman lubang $\left.{ }^{-1}\right)$. Faktor kedua adalah Varietas, terdiri dari level perlakuan $\mathrm{V}_{1}$ : Lokal Bukit, $\mathrm{V}_{2}$. Lokal Kefa 1 (Pena Muti M'asa), $\mathrm{V}_{3}$ : Lokal Kefa 2 (Pena Molo M'asa) dan $\mathrm{V}_{4}$ Bisi-2. Terdapat 16 kombinasi perlakuan, masing-masing diulang sebanyak tiga kali sehingga diperlukan 48 petak percobaan.

Benih jagung varietas Lokal Bukit merupakan varietas jagung yang sudah lama dibudidayakan masyarakat di lingkungan Taman Mumbul, varietas loka Kefa yaitu Pena muti m'asa (varietas lokal Kefa 1) dan Pena molo m'asa (varietas lokal Kefa 2), keduanya diambil dari masyarakat di Desa Loeram dan Desa Oinbit, Kecamatan Insana, Kabupaten TTU, serta benih jagung varietas Bisi-2 yang dibeli dari toko pertanian di Denpasar. Beberapa parameter yang diamati dan cara pengukurannya sebagai berikut:

a) Indeks luas daun (ILD)

Pengamatan dilakukan umur 21 hst, 42 hst, 49 hst dan 56 hst. Pengukuran dilakukan dengan terlebih dahulu mengukur luas per daun menggunakan kertas milimeter blok, kemudian menghitung konstanta dengan membagi luas daun sebenarnya (sesuai gambar pada kertas milimeter blok) dengan panjang x leba daun maksimal. Selanjutnya untuk menghitung luas daun per tanaman dilakukan 
dengan mengalikan jumlah daun tanaman ${ }^{-1}$ dengan luas daun ${ }^{-1}$. Rumus untuk menghitung ILD:

$$
\mathrm{ILD}=\frac{\mathrm{Ld}}{\mathrm{Lt}}
$$

Dimana: ILD = Indeks luas daun, $\mathrm{Ld}=$ Luas daun $\operatorname{tanaman}^{-1}\left(\mathrm{~cm}^{2}\right)$, dan Lt $=$ Luas lahan yang diduduki tanaman $\left(\mathrm{cm}^{2}\right)$.

b) Berat biji k.a $12 \%$ tongkol ${ }^{-1}, \tan ^{-1}$ dan ha $^{-1}$

Parameter ini diukur dengan terlebih dahulu menghitung Kadar air (k.a.) biji saat panen, dengan rumus:

$$
\text { Kadar air biji saat panen }=\frac{A-B}{A} \times 100 \%
$$

Dimana: $\mathrm{A}=$ Berat biji $(\mathrm{Bb})$ panen $\operatorname{tanaman}^{-1}(\mathrm{~g}), \mathrm{B}=$ Berat Kering Oven biji $\operatorname{tanaman}^{-1}(\mathrm{~g})$

\section{$>\quad$ Berat biji k.a $12 \%$ tongkol $^{-1}$}

$$
\text { Bb k.a. } 12 \% \text { tonkol }^{-1}=\frac{\text { Bb k. a. } 12 \% \text { ubinan }^{-1}}{\text { jumlah tongkol dalam ubinan }}
$$

Dimana ukuran ubinan adalah $1,12 \mathrm{~m}^{2}$.

$>\quad$ Berat biji k.a. $12 \%$ per tanaman $\left(\tan ^{-1}\right)$ dihitung dengan rumus:

$$
\begin{aligned}
& \text { Bb k. a. } 12 \% \\
& =\frac{\left(100-\text { k. a. biji tan. }{ }^{-1}\right) \%}{(100-12) \%} \text { xberat biji saat panen tan. }{ }^{-1} g
\end{aligned}
$$

Berat biji k.a. $12 \%$ per hektar $\left(\mathrm{ha}^{-1}\right)$ dihitung dengan rumus:

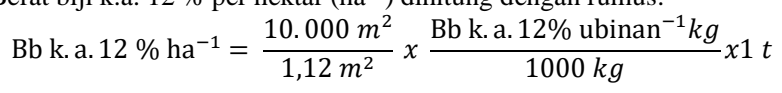

c) Berat biji kering oven $\tan ^{-1}$ dan $\mathrm{ha}^{-1}$

Parameter-parameter ini diukur dengan menimbang sub sampel biji kering panen dalam ubinan sebanyak $200 \mathrm{~g}$ kemudian dikeringkan dalam oven. Bera kering oven (BKO) sub sampel tersebut kemudian dikonversi menjadi berat biji kering oven ubinan ${ }^{-1}$. Untuk menghitung berat biji kering oven $\tan ^{-1}$ digunakan rumus:

BKO biji tan $^{-1}=\frac{\text { Berat biji kering oven ubinan-1 }}{\text { Jumlah tanaman dalam ubinan }} \mathrm{g}$

Selanjutnya untuk menghitung berat biji kering oven per hektar $\left(h a^{-1}\right)$ digunakan rumus:

$$
\begin{aligned}
& \text { BKO biji ha }{ }^{-1} \\
& =\frac{10.000 \mathrm{~m}^{2}}{1,12 \mathrm{~m}^{2}} x \frac{\text { Berat biji k. a. } 12 \% \text { tan. }^{-1}\left(1,12 \mathrm{~m}^{2}\right)^{-1} \mathrm{~g}}{10.000 \mathrm{~g}} \times 1 \mathrm{t}
\end{aligned}
$$

\section{Hasil dan Pembahasan}

Hasil analisis data menunjukkan bahwa interaksi antara perlakuan populasi dengan varietas tidak berpengaruh nyata terhadap berat biji k.a $12 \%$,

\begin{tabular}{|c|c|c|c|c|}
\hline \multirow{2}{*}{ No. } & \multirow{2}{*}{ Variabel } & \multicolumn{3}{|c|}{ Perlakuan } \\
\hline & & $\mathrm{P}$ & $\mathrm{V}$ & $\mathrm{PxV}$ \\
\hline 1. & $\begin{array}{l}\text { Indeks luas daun pada umur: } 21,42 \text {, } \\
49 \text { dan } 56 \text { hst }\end{array}$ & $* *$ & $* *$ & $\mathrm{TN}$ \\
\hline 2. & Berat biji k.a. $12 \% \tan ^{-1}$ & $* *$ & $* *$ & $* *$ \\
\hline 3. & Berat biji k.a. $12 \%$ ha $^{-1}$ & $* *$ & $* *$ & $\mathrm{TN}$ \\
\hline 4. & Berat biji kering oven tongkol $^{-1}$ & $* *$ & $* *$ & $*$ \\
\hline 5 . & Berat biji kering oven $\tan ^{-1}$ & $* *$ & $* *$ & $\mathrm{TN}$ \\
\hline
\end{tabular}
berat biji kering oven $\tan ^{-1}$ dan ha-1 tetapi berpengaruh terhadap berat biji k.a.12\% dan kering oven tongkol ${ }^{-1}$. Perlakuan populasi secara tunggal berpengaruh terhadap semua variabel yang diamati kecuali indeks luas daun umur 42 hst. Varietas hanya berpengaruh nyata terhadap semua parameter yang diamati.

Tabel 1. Signifikansi Pengaruh Perlakuan Populasi (P) dan Varietas (V) serta Interaksinya $(\mathrm{PxV})$ terhadap Variabel Pertumbuhan dan Hasil Jagung Lokal di Lahan Kering.

Keterangan: $* \quad=$ berpengaruh nyata $(\mathrm{P}<0,05)$,

$$
* * \text { = berpengaruh sangat nyata }(\mathrm{P}<0,01)
$$$$
\mathrm{TN}=\text { berpengaruh tidak nyata }(\mathrm{P} \geq 0,05)
$$

a. Pengaruh Tunggal Populasi dan Varietas Jagung Lokal

1. Indeks luas daun pada umur 21, 42, 49 dan 56 hst

Indeks luas daun meningkat dengan meningkatnya populasi tanaman dan bertambahnya umur tanaman (Tabel 2). Pada populasi dari 285.714 dan 357.143 tanaman $\mathrm{ha}^{-1}$ indeks luas daun berbeda nyata pada umur 21 hst dan 49 hst. Pada umur 56 hst terjadi peningkatan indeks luas daun berbeda nyata antara populasi 285.714 dengan populasi 428.571 dan semakin besar indeks luas daun pada populasi 500.000 tanaman ha $^{-1}$ (Tabel 2).

Varietas Lokal Kefa 2 mempunyai indeks luas daun terbesar pada umur 21 hst sampai 56 hst tetapi tidak berbeda nyata dengan varietas Lokal Bukit pada umur
42 hst dan 56 hst (Tabel 2).

2. Berat biji k.a $12 \% \tan ^{-1}$ dan ha ${ }^{-1}$

Meningkatnya populasi tanaman menjadi 357.143, 428.571 dan 500.000 tanaman ha ${ }^{-1}$ menyebabkan semakin menurunnya berat biji k.a $12 \% \tan ^{-1}$ masing masing $16,13 \%, 85,28 \%$ dan $92,69 \%$ serta berat biji ha ${ }^{-1}$ masing-masing $16,17 \%$, $86,10 \%$ dan $92,14 \%$ dibandingkan hasil pada populasi 285.714 tanaman ha ${ }^{-1}$. Varietas Lokal Bukit menghasilkan berat biji k.a $12 \% \tan ^{-1}$ dan ha ${ }^{-1}$ masing masing 37,47\% dan 37,23\% lebih tinggi dibandingkan varietas Lokal Kefa 1 .

Varietas Bisi 2 menghasilkan berat biji k.a $12 \% \tan ^{-1}$ masing-masing 42,51\% dan $26,90 \%$ lebih tinggi serta berat biji k.a $12 \%$ ha $^{-1}$ masing-masing $37,23 \%$ dan 26,92\% lebih tinggi dibandingkan varietas Lokal Kefa 1 dan Kefa 2 (Tabel 3).

Tabel 2. Pengaruh Tunggal Populasi dan Varietas terhadap Indeks Luas Daun pada Umur 21, 42.49 dan 56 hst

\begin{tabular}{lcccc}
\hline \multirow{2}{*}{ Perlakuan } & \multicolumn{4}{c}{ Indeks luas daun pada umur } \\
\cline { 2 - 5 } & $21 \mathrm{hst}$ & $42 \mathrm{hst}$ & $49 \mathrm{hst}$ & $56 \mathrm{hst}$ \\
\hline Populasi (tan.ha $\left.{ }^{-1}\right)$ & & & & \\
$285.714\left(\mathrm{P}_{1}\right)$ & $0,823 \mathrm{~b}$ & $8,077 \mathrm{a}$ & $16,930 \mathrm{~b}$ & $26,660 \mathrm{~b}$ \\
$357.143\left(\mathrm{P}_{2}\right)$ & $1,095 \mathrm{a}$ & $9,166 \mathrm{a}$ & $19,448 \mathrm{a}$ & $28,657 \mathrm{ab}$ \\
$428.571\left(\mathrm{P}_{3}\right)$ & $1,192 \mathrm{a}$ & $9,704 \mathrm{a}$ & $19,944 \mathrm{a}$ & $29,748 \mathrm{a}$ \\
$500.000\left(\mathrm{P}_{4}\right)$ & $1,332 \mathrm{a}$ & $10,409 \mathrm{a}$ & $20,733 \mathrm{a}$ & $31,057 \mathrm{a}$ \\
BNT 5\% & 0,254 & - & 2,216 & 2,288 \\
Varietas & & & & \\
Lokal Bukit (V1) & $0,692 \mathrm{~b}$ & $11,617 \mathrm{a}$ & $19,706 \mathrm{~b}$ & $31,967 \mathrm{a}$ \\
Lokal Kefa 1 (V2) & $0,901 \mathrm{~b}$ & $7,309 \mathrm{~b}$ & $15,172 \mathrm{c}$ & $22,539 \mathrm{c}$ \\
Lokal Kefa 2 (V3) & $1,446 \mathrm{a}$ & $20,417 \mathrm{a}$ & $22,632 \mathrm{a}$ & $32,809 \mathrm{a}$ \\
Bisi 2 (V4) & $1,027 \mathrm{~b}$ & $8,093 \mathrm{~b}$ & $19,547 \mathrm{~b}$ & $28,807 \mathrm{~b}$ \\
BNT 5\% & 0,254 & 2,317 & 2,216 & 2,288 \\
\hline Keterangan &
\end{tabular}

Keterangan: Angka-angka yang diikuti oleh huruf yang sama pada perlakuan dan variabel yang sama adalah tidak berbeda nyata pada uji BNT $5 \%$.

Tabel 3. Pengaruh Tunggal Populasi dan Varietas terhadap Berat Biji k.a. 12\%

\begin{tabular}{|c|c|c|}
\hline Perlakuan & $\begin{array}{l}\text { Berat biji kering oven } \\
\qquad\left(\mathrm{g} \mathrm{tan}^{-1}\right)\end{array}$ & $\begin{array}{c}\text { Berat biji kering oven } \\
\left(\mathrm{t} \mathrm{ha}^{-1}\right)\end{array}$ \\
\hline \multicolumn{3}{|l|}{ Populasi (tan.ha $\left.{ }^{-1}\right)$} \\
\hline $285.714\left(\mathrm{P}_{1}\right)$ & $135,23 \mathrm{a}$ & $7,73 \mathrm{a}$ \\
\hline $357.143\left(\mathrm{P}_{2}\right)$ & $113,43 \mathrm{~b}$ & $6,48 \mathrm{~b}$ \\
\hline $428.571\left(\mathrm{P}_{3}\right)$ & $19,91 \mathrm{c}$ & $1,14 \mathrm{c}$ \\
\hline $500.000\left(\mathrm{P}_{4}\right)$ & $10,61 \mathrm{c}$ & $0,61 \mathrm{c}$ \\
\hline BNT 5\% & 18,22 & 1,04 \\
\hline \multicolumn{3}{|l|}{ Varietas } \\
\hline Lokal Bukit (V1) & $80,12 \mathrm{ab}$ & $4,58 \mathrm{ab}$ \\
\hline Lokal Kefa 1 (V2) & $49,63 \mathrm{c}$ & $2,84 \mathrm{c}$ \\
\hline Lokal Kefa 2 (V3) & $63,10 \mathrm{bc}$ & $3,60 \mathrm{bc}$ \\
\hline Bisi 2 (V4) & $86,34 \mathrm{a}$ & $4,93 \mathrm{a}$ \\
\hline BNT $5 \%$ & 18,22 & 1,04 \\
\hline
\end{tabular}
$\tan ^{-1}$ dan $\mathrm{ha}^{-1}$

\begin{tabular}{ccc}
\hline Perlakuan & $\begin{array}{c}\text { Berat biji k.a. 12\% } \\
\left(\mathrm{g} \mathrm{tan}^{-1}\right)\end{array}$ & $\begin{array}{c}\text { Berat biji k.a. 12\% } \\
\left(\mathrm{t} \mathrm{ha}^{-1}\right)\end{array}$ \\
\hline
\end{tabular}

Populasi (tan.ha-1)

$\begin{array}{lcl}285.714\left(\mathrm{P}_{1}\right) & 153,67 \mathrm{a} & 8,78 \mathrm{a} \\ 357.143\left(\mathrm{P}_{2}\right) & 128,89 \mathrm{~b} & 7,36 \mathrm{~b} \\ 428.571\left(\mathrm{P}_{3}\right) & 22,62 \mathrm{c} & 1,22 \mathrm{c} \\ 500.000\left(\mathrm{P}_{4}\right) & 11,23 \mathrm{c} & 0,69 \mathrm{c} \\ \text { BNT 5\% } & 20,76 & 1,19 \\ \quad \text { Varietas } & & \\ \text { Lokal Bukit (V1) } & 90,20 \mathrm{ab} & 5,13 \mathrm{ab} \\ \text { Lokal Kefa 1 (V2) } & 56,40 \mathrm{c} & 3,22 \mathrm{c} \\ \text { Lokal Kefa 2(V3) } & 71,71 \mathrm{bc} & 4,10 \mathrm{bc} \\ \text { Bisi 2 (V4) } & 98,10 \mathrm{a} & 5,61 \mathrm{a} \\ \text { BNT 5\% } & 20,76 & 1,19\end{array}$

Keterangan: Angka-angka yang diikuti oleh huruf yang sama pada perlakuan dan variabel yang sama adalah tidak berbeda nyata pada uji BNT 5\%

Tabel 4. Pengaruh Tunggal Populasi dan Varietas terhadap Berat Biji Kering Oven $\tan ^{-1}$ dan ha-1

Keterangan: Angka-angka yang diikuti oleh huruf yang sama pada perlakuan dan variabel yang sama adalah tidak berbeda nyata pada uji BNT $5 \%$.

3. Berat biji kering oven $\tan ^{-1}$ dan ha ${ }^{-1}$

Berat biji kering oven $\tan ^{-1}$ dan $\mathrm{ha}^{-1}$ secara nyata menurun ketika populasi meningkat menjadi 357.143, 428.571 dan 500.000 tanaman ha $^{-1}$, berturut-turut $16,12 \%, 85,25 \%$ dan $91,15 \%$ dibandingkan pada populasi 285.714 tanaman ha ${ }^{1}$. Varietas Lokal Bukit menghasilkan berat biji kering oven $\tan ^{-1}$ dan $\mathrm{ha}^{-1}$ yang tidak berbeda dengan varietas Lokal Kefa 2 dan Bisi 2, tetapi secara nyata lebih tinggi masing-masing 38,06\% dan 37,99\% dibandingkan varietas Lokal Kefa 1 
(Tabel 4).

4. Pengaruh Interaksi Perlakuan Populasi dan Varietas Jagung Lokal

a. Berat biji k.a. $12 \%$ tongkol $^{-1}$

Varietas Lokal Bukit dan Kefa 2 menghasilkan berat biji k.a. 12\% tongkol 1 yang lebih tinggi dibandingkan dua varietas lainnya tetapi keduanya tidak berbeda nyata (Tabel 5). Semakin tinggi populasi tanaman semakin menurun berat biji k.a. $12 \%$ tongkol $^{-1}$ (Tabel 5).

Tabel 5. Pengaruh Interaksi antara Populasi dan Varietas terhadap Berat Biji k.a. $12 \%$ Tongkol $^{-1}$

\begin{tabular}{lcccc}
\hline \multirow{2}{*}{ Perlakuan } & \multicolumn{4}{c}{ Berat biji k.a. 12\% tongkol ${ }^{-1}(\mathrm{~g})$} \\
\cline { 2 - 5 } & 285.714 & 357.143 & 428.571 & 500.000 \\
\cline { 2 - 5 } & & & \\
Varietas & $137,77 \mathrm{a}$ & $120,57 \mathrm{~b}$ & $36,69 \mathrm{ef}$ & $30,06 \mathrm{f}$ \\
Lokal Bukit & $102,35 \mathrm{c}$ & $99,35 \mathrm{c}$ & $43,21 \mathrm{de}$ & $28,58 \mathrm{f}$ \\
Lokal Kefa 1 & $133,67 \mathrm{a}$ & $120,18 \mathrm{~b}$ & $47,46 \mathrm{~d}$ & $47,67 \mathrm{~d}$ \\
Lokal Kefa 2 & $121,74 \mathrm{~b}$ & $98,67 \mathrm{c}$ & $41,46 \mathrm{de}$ & $33,90 \mathrm{ef}$ \\
Bisi 2 &
\end{tabular}

Keterangan: Angka-angka yang diikuti oleh huruf yang sama adalah tidak berbeda nyata pada uji jarak berganda Duncan 5\%

b. Berat biji kering oven tongkol ${ }^{-1}$

Varietas Lokal Bukit menghasilkan jagung dengan Berat biji kering oven tongkol $^{-1}$ yang lebih berat, berbeda nyata dengan Bisi 2 tetapi tidak berbeda nyata dengan hasil jagung Lokal Kefa 2 (Tabel 6). Semakin banyak tanaman lubang ${ }^{-1}$, berat biji kering oven tongkol ${ }^{-1}$ menurun pada semua varietas kecuali Lokal Kefa 1 dan Lokal Kefa 2 (Tabel 6).

Tabel 6.Pengaruh Interaksi antara Populasi dan Varietas terhadap Berat Biji Kering Oven Tongkol ${ }^{-1}$

\begin{tabular}{lcccc}
\hline \multirow{2}{*}{ Perlakuan } & \multicolumn{5}{c}{ Berat biji kering oven tongkol ${ }^{-1}(\mathrm{~g})$} \\
\cline { 2 - 5 } & 285.714 & 357.143 & 428.571 & 500.000 \\
\cline { 2 - 5 } & & & \\
Varietas & $121,23 \mathrm{a}$ & $106,10 \mathrm{~b}$ & $32,29 \mathrm{de}$ & $26,45 \mathrm{e}$ \\
Lokal Bukit & $90,07 \mathrm{c}$ & $87,43 \mathrm{c}$ & $35,38 \mathrm{de}$ & $25,12 \mathrm{e}$ \\
Lokal Kefa 1 & $117,63 \mathrm{ab}$ & $105,76 \mathrm{~b}$ & $41,76 \mathrm{~d}$ & $41,95 \mathrm{~d}$ \\
Lokal Kefa 2 & $107,13 \mathrm{~b}$ & $86,83 \mathrm{c}$ & $36,49 \mathrm{de}$ & $29,83 \mathrm{de}$ \\
Bisi 2 & &
\end{tabular}

Keterangan: Angka-angka yang diikuti oleh huruf yang sama adalah tidak

berbeda nyata pada uji jarak berganda Duncan 5\%

5. Hubungan antara Populasi Tanaman dengan Berat Biji K.a.12\% dan Berat Biji Kering Oven ha ${ }^{-1}$

Hubungan antara jumlah tanaman (populasi) dengan berat biji k.a.12\% maupun dengan berat biji kering oven ha $^{-1}$ adalah berbentuk linier dengan persamaan regresi masing-masing untuk berat biji k.a.12\% adalah $\mathrm{y}_{\mathrm{k} . \mathrm{a}} \mathrm{k} \%=$ $21,238-0,0000426 \mathrm{x} ; \mathrm{R}^{2}=0,893 ; \mathrm{r}=0,09450$ dan untuk berat biji kering oven adalah $\mathrm{y}_{\mathrm{ko}}=21,592-0,0000461 \mathrm{x} ; \mathrm{R}^{2}=0,886 ; \mathrm{r}=0,09413$ (Gambar 1). Dalam percobaan ini belum ditemukan populasi optimum untuk memperoleh hasil jagung maksimum.

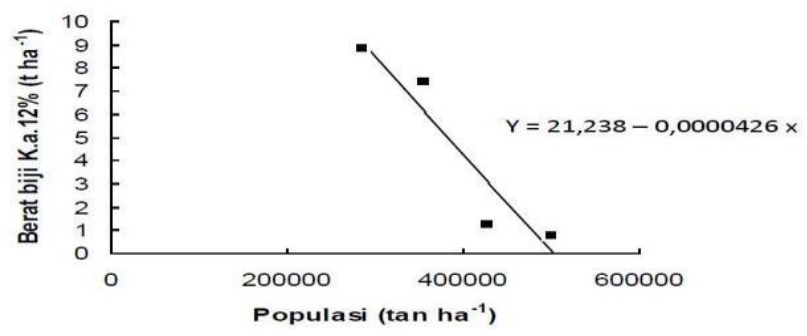

Gambar 1. Hubungan antara Populasi Tanaman ha-1 dengan Berat Biji Jagung k.a. $12 \%$ ha $^{-1}$

6. Pembahasan

Perlakuan kombinasi populasi dan varietas secara nyata berinteraksi pada pengamatan berat biji k.a.12\% tongkol ${ }^{-1}$ (Tabel 5) dan berat kering oven tongkol ${ }^{1}$ (Tabel 6). Varietas lokal bukit memberikan hasil jagung dengan berat biji k.a $12 \%$ tongkol $^{-1}$ dan berat biji kering oven tongkol ${ }^{-1}$ paling berat tetapi tidak berbeda nyata dengan hasil dari varietas Lokal Kefa 2 (Tabel 5 dan Tabel 6).

Populasi tanaman secara tunggal berpengaruh nyata terhadap semua variabel yang diamati (Tabel 1). Indeks luas daun meningkat dengan meningkatnya populasi tanaman (Tabel 2). Peningkatan indeks luas daun tersebut disebabkan oleh jumlah tanaman per lubang yang meningkat, terjadi kompetisi antar tanaman terhadap cahaya sehingga tanaman lebih memaksimalkan pertumbuhan vegetatifnya. Hal ini berdampak pada hasil yang ditunjukkan parameter berat biji k.a. $12 \% \tan ^{-1}$, Berat biji k.a. $12 \%$ ha $^{-1}$, Berat biji kering oven tan.$^{-1}$ tertinggi $135,23 \mathrm{~g}$ tan. ${ }^{-1}$ dan Berat biji kering oven ha ${ }^{-1}$ tertinggi $7,73 \mathrm{t} \mathrm{ha}^{-1}$ semakin menurun dengan meningkatnya populasi tanaman (Tabel 3 dan Tabel 4). Penurunan hasil tersebut disebabkan oleh persaingan yang sangat kuat di antara tanaman sehingga semua hasil fotosintesis lebih digunakan untuk pertumbuhan vegetatif sedangkan untuk pengisian tongkol dan biji semakin berkurang. Hal ini sesuai dengan pernyataan Janick dkk., (1974), bahwa peningkatan kepadatan populasi sampai optimum, pada awalnya akan meningkatkan hasil per satuan luas, tetapi jika titik optimum terlewati maka hasil akan menurun per satuan luas.

Varietas secara tunggal berpengaruh nyata terhadap semua variabel yang diamati (Tabel 1). Indeks luas daun yang lebih besar pada varietas Lokal Buki dan varietas Lokal Kefa 2 memproduksi lebih banyak asimilat untuk meningkatkan hasilnya, yang ditunjukkan parameter berat biji k.a. $12 \%$, berat kering oven $\tan ^{-1}$ dan ha-1 walaupun hasil tersebut tidak berbeda nyata dengan varietas Bisi 2 yang masih lebih tinggi (Tabel 3, Tabel 4 dan Tabel 5).

Hasil penelitian ini menunjukkan populasi optimum semua varietas jagung lokal dan Bisi 2 adalah 285.714 tanaman ha-1 atau 4 tanaman lubang ${ }^{-1}$, dengan jarak tanam $70 \mathrm{~cm} \times 20 \mathrm{~cm}$, terbukti pada hubungan antara populasi dengan berat biji k.a. $12 \%$ dan kering oven ha ${ }^{-1}$ (Gambar 1). Varietas Lokal Bukit secara tunggal memberikan hasil dengan berat biji kering oven 90,20 g tan. ${ }^{-1}$ dan berat biji kering oven $5,13 \mathrm{t} \mathrm{ha}^{-1}$, disusul Varietas lokal Kefa-2 dengan berat biji kering oven $\tan ^{-1} 63,10 \mathrm{~g}$ dan berat biji kering oven 3,60 $\mathrm{t} \mathrm{ha}^{-1}$, serta yang paling rendah adalah Varietas lokal Kefa-1 dengan berat biji kering oven $\tan ^{-1} 49,63 \mathrm{~g}$ dan berat biji kering oven 2,84 $\mathrm{tha}^{-1}$.

Hasil tersebut menunjukkan bahwa varietas lokal bukit merupakan varietas yang lebih cocok ditanam di lahan kering lingkungan Taman Mumbul, kabupaten Badung. Varietas yang aslinya adalah varietas Bisma itu memiliki daun lebih tebal dan hijau, serta sudah beradaptasi dengan kondisi lingkungan tersebut, . Selain itu disebabkan pula karena kepadatan populasinya yang rendah sehingga tidak terjadi kompetisi antar tanaman dalam menyerap hara, air dan cahaya matahari. Hal itu sesuai pula dengan hasil penelitian Wijayanto (2005) di lahan kering Manukaya, Tampaksiring, bahwa pada sistem monokultur jagung Bisma dengan jarak tanam $80 \mathrm{~cm}$ x $40 \mathrm{~cm}$ (dua tanaman lubang-1), memberikan hasil biji kering k.a. $15 \%$ lebih tinggi dibandingkan pada jarak tanam $160 \mathrm{~cm} \mathrm{x}$ $40 \mathrm{~cm}$.

\section{Simpulan}

1. Interaksi nyata pada hasil dari varietas lokal bukit dan populasi 285.714 tanaman ha-1, yaitu berat biji k.a.12\% tongkol $^{-1}(137,77 \mathrm{~g})$ dan berat biji kering oven tongkol ${ }^{-1}(121,23 \mathrm{~g})$

2. Populasi 285.714 tan.ha ${ }^{-1}$ merupakan populasi optimum yang memberikan hasil tertinggi untuk semua varietas jagung lokal.

3. Varietas Lokal Bukit secara tunggal memberikan hasil dengan berat biji kering oven 90,20 $\mathrm{g} \mathrm{tan}^{-1}$ dan berat biji kering oven 5,13 $\mathrm{t} \mathrm{ha}^{-1}$

4. Varietas Lokal Bukit berpotensi dikembangkan di lahan kering daerah Taman Mumbul, Kuta Selatan pada populasi 285.714 tan.ha $^{-1}$ (4 tan.lubang ${ }^{-1}$ ).

Pustaka

Amim, H.H., Nurmauli, N. 2004. Respons Dua Varietas Jagung terhadap Pemberian Sulfomag Plus pada Lahan Kering. Laporan Hasil Penelitian. Lampung: Universitas Lampung.

BKPMD NTT. 2008. Jagung. (cited 2009 June 19th). Available from: URL: http//www.bkpmd.nttprov.go.id. 70

Gardner, F. P., Pearce, R. B., Mitchell, R. L. 1991. Fisiologi Tanaman Budidaya (Terjemahan). Jakarta: Universitas Indonesia Press

Janick, J., Schery, R., Frank, W. W., Ruttan, V. W. 1974. Plant Science. An Introduction to World Crops. San Fransisco: Freman and Compani.

Jumin, H. 1989. Ekologi Tanaman Suatu Pendekatan Fisiologi. Jakarta: PT. Rajawali Grafindo Persada.

Mediastari, A. A. P. A. 2009. Pengaruh Populasi Tanaman terhadap Hasil Biji, Berat dan Kualitas Hijauan Beberapa Varietas Jagung (Zea mays L.) Setelah Musim Tanam di Lahan Kering. (Tesis). Denpasar: Universitas Udayana.

Sudiana, I M. 2007. Pengaruh Jarak Tanam terhadap Hasil Biji, Kadar Protein Kasar, Serat Kasar dan Ekstrak Bebas Nitrogen Brangkasan Beberapa Varietas Jagung (Zea mays L.) Unggul di Lahan Kering. (Tesis). Denpasar: Universitas Udayana.

Wijaya, I K. A. 2005. Pengaruh Populasi Tanaman dan Penggunaan Mulsa terhadap Populasi Gulma dan Hasil Pucil Jagung Manis (Zea mays saccharata Sturt). (Tesis). Denpasar: Universitas Udayana.

Wijayanto, B. H. 2005. Pengaruh Jarak Tanam dan Dosis Nitrogen terhadap Pertumbuhan dan Hasil Jagung (Zea mays L.) dan Kacang Tanah (Arachis hypogaea L.) dalam Sistem Tumpangsari di Lahan Kering. (Tesis). Denpasar: Universitas Udayana

Zubachtirodin, M.S., Pabbage, Subandi. 2009. Wilayah Produksi dan Potensi Pengembangan Jagung. (cited 2010 Juli 25th). Available from: balitsereal.litbang.deptan.go.id. 